\title{
ANDRZEJ BAŁANDYNOWICZ
}

\section{PARADYGMAT TOŻSAMOŚCI PODSTAWĄ KREOWANIA WIELOPASMOWEGO I ZINTEGROWANEGO MODELU TRITMENTU AUTORESOCJALIZACJI}

\begin{abstract}
Abstrakt: Resocjalizacja z zastosowaniem środków probacyjnych to proces kształtowanie się teorii i praktycznych metod postępowania w stosunku do osób naruszających porządek prawny w ramach zinstytucjonalizowanego systemu reakcji karnoprawnych. Oryginalność i szeroki zakres probacji zakorzeniony został $\mathrm{w}$ rozwiniętych i wyspecjalizowanych agencjach pomocowych, w innowacyjnej praktyce oraz w tworzeniu pozainstytucjonalnych środków uzupełniających system zakładów i placówek zamkniętych dla skazanych. W prezentowanym obszernym studium teoretycznym dokonano wnikliwej interdyscyplinarnej analizy wielopasmowej teorii resocjalizacji oraz podstawowych paradygmatów składających się na zjawisko integracji społecznej i autoresocjalizacji skazanych. Wynikające z omawianego tekstu wnioski będą szczególnie przydatne w pracy pedagogów resocjalizacyjnych, kuratorów sądowych, pracowników socjalnych, wychowawców w instytucjach penitencjarnych i socjoterapeutycznych.
\end{abstract}

Słowa kluczowe: probacja, reintegracja społeczna skazanych, tożsamość, autoresocjalizacja, polityka kryminalna

\section{PRZEDZAŁOŻENIOWE MYŚLENIE AKSJOLOGICZNE DOTYCZĄCE PROCESU REINTEGRACJI SPOŁECZNEJ}

Każdy wywód, każda refleksja intelektualna powinna być poprzedzona systemem założeń wstępnych. Na poziomie metametodologii tworzymy tzw. paradygmaty, czyli określone tezy, pewniki, które powinny koncentrować uwagę na sensie ich struktury, dynamiki, przekroju i być sobie zbieżne (Abramowski 1986).

Podstawowym elementem, który chciałbym wskazać jako założenie przedwstępne do oceny, czym jest reintegracja, jaka jest jej po pierwsze treść, a po drugie na 
czym polega jej istota - jest kwestia, jak określamy to zjawisko w przestrzeni nauk interdyscyplinarnych. To będzie założenie mówiące o trzech pojęciach inteligencji: inteligencji subiektywnej, obiektywnej i inteligencji w kategoriach tzw. myślenia aksjologicznego, które dopiero pozwala nam przejść do zagadnień treści, istoty badanego stanu rzeczy, w tym wypadku zagadnienia społeczno-osobowego dotyczącego problemu, jak człowiek włącza się w struktury grupowe, w struktury przestrzenne (Ebner 2006).

Pojęcie inteligencji subiektywnej to pojęcie, które wiąże się z przeżywaniem określonego problemu, stanu rzeczy na poziomie pewnych kompetencji osobowych (Gadacz 2007). W określonym zbiorze osób, w grupie, w społeczeństwie, państwie czy też w narodzie - poszczególni reprezentanci artykułują swoje myśli, głoszą pewne tezy, np. dotyczące kwestii, kim jest człowiek, a także kim jest człowiek zintegrowany, człowiek, który jest sierotą, gdzie powinien przeżywać swój proces socjalizacji, jaki jest człowiek, który opuszcza zakład penitencjarny po odbyciu wyroku za określony czyn inkryminowany, w jaki sposób powinien być włączony w struktury lokalne czy w struktury życia publiczno-społecznego (Ignaczak 1986). Człowiek stary, który najczęściej w naszym społeczeństwie jest nikomu niepotrzebny, pozostaje sam sobie. Proces reintegracji polega na tym, żeby okres starości zyskał ten sam wymiar co okres dzieciństwa lub adolescencji młodzieńczej, czyli żeby był przeżywany w strukturach grupy czy w strukturach społecznych na podobnym poziomie w sensie treści, istoty, czyli jakości tego życia (Kaczyńska 1992).

Zatem myślenie subiektywne będzie przynależne poszczególnym osobom. Każdy człowiek uformowany jest poprzez swoją wiedzę i kompetencje, które wynikają w pewnym stopniu ze znajomości problematyki stanowiącej o istocie owych kompetencji (Życiński 1985). Trudno żeby na przykład premier rządu wypowiadał się na temat dewiantów seksualnych w sposób podlegający myśleniu obiektywnemu czy aksjologicznemu. Premier wypowiada się w rygorach właściwych dla myślenia subiektywnego, co należy robić z przestępcami, którzy mają skłonności do zaburzeń psychicznych. Notabene chcę powiedzieć, że takich zaburzeń psychicznych w sensie zachowań seksualnych zgodnie z nomenklaturą WHO jest ponad 260 i podobnie wiele jest różnych typów zaburzeń osobowości (Urban 2000).

1 stycznia 2010 roku Międzynarodowa Organizacja Zdrowia zrezygnowała z powodów materialnych z klasyfikacji tzw. chorób psychicznych i nazywać je będziemy zaburzeniami osobowości, bo bardzo często w tych wszystkich stanach wpływ otoczenia będzie warunkował jak gdyby stan zaburzonej równowagi czynności psychicznych człowieka czy różnych struktur zaburzenia jego osobowości (Allport 1985). Jeżeli mamy do czynienia z dewiantem seksualnym, który popełnia czyn przestępczy, to trzeba się zastanowić i wyartykułować, jaka struktura społeczna, instytucja czy jakieś ciało, określony podmiot, byłby kompetentny do tego, żeby 
podjąć się działania leczniczego lub działania resocjalizacyjnego, a następnie działania reintegracyjnego. Czyli najpierw zmienić, skontrolować, a następnie włączyć tego człowieka do grupy czy do społeczeństwa (Szołtysek 1998).

Oczywiście wypowiedź naszego premiera na temat kastracji chemicznej jest wypowiedzią na poziomie wiedzy, jaką posiada. Słyszymy generalnie opinię wielu ludzi, która jest często przeniesieniem wiadomości prasowych i telewizyjnych, ponieważ badania empiryczne pokazują, że problem kompetencji odbiorców na poziomie inteligencji subiektywnej jest kształtowany przez media, czyli przez środki komunikacji masowej (Radochoński 2000).

Według badań na poziomie inteligencji subiektywnej mamy obecnie 70 proc. analfabetów wtórnych, czyli funkcjonalnych - a więc człowiek czyta, potrafi odtworzyć to, co czyta, natomiast nie potrafi odpowiedzieć na proste pytania: czemu to służy?, skąd to wynika? i czy tak powinno być? Każdy człowiek jest obserwatorem otaczającej nas rzeczywistości, każdy ma prawo do myślenia, każdy z nas uruchamia racjonalizację intelektualną (Morris 1956). Od siódmego roku życia centralny układ nerwowy w sposób rzeczywisty rejestruje fakty i bodźce zewnętrzne. W związku z tym przekaz społeczny jest przekazem wielu ludzi. Wskazuje on, że nasze społeczeństwo jest bardzo punitywne, czyli restryktywne, przejawia wyraźne postawy karcące w stosunku do osób, które są dewiantami, prezentuje postawy odtrąceniowe, eliminacyjne w stosunku do osób, które wchodzą w wyraźny konflikt z normami tworzonymi przez prawo danej społeczności (Hołyst 1999).

Polska znajduje się, według badań empirycznych, w układzie państw Europy prawie na ostatnim miejscu przed Ukrainą, Białorusią, Rosją w zakresie punitywizmu, czyli reagowania bardzo karcącego, o dużym stopniu dolegliwości w stosunku do odmieńców, osób o dużym stopniu dewiacji czy ludzi wchodzących w role przestępcze (Jankowski 1981). To artykułowanie opinii czy ocen jest także częścią inteligencji subiektywnej. Zatem każdy - czy jest to absolwent wyższych studiów, czy kucharka - ma prawo do wypowiadania się, jest poddawany tzw. oddziaływaniu poprzez środki masowego przekazu i na podstawie tzw. wartościowania wtórnego odbioru tej informacji wytwarza się ocena, reakcja, zachowanie, które zdefiniowałem: nasze społeczeństwo jest punitywne i karzące (Gademer 2002).

Wreszcie każdy człowiek ma jakieś doświadczenia, a doświadczenie jest to przymiot wypełniania pewnych ról, wypełniania pewnych funkcji. Człowiek po prostu uczestniczy na poziomie aktywności zawodowej w przetwarzaniu przedmiotów naszego otoczenia i ten element jego działania na poziomie aktywizacji zawodowej nazywamy pewnym doświadczeniem uczącym (Drwal 1979). Nauczyciel, który uczy dzieci, wychowawca zakładu poprawczego, który wchodzi w pewne interakcje z wychowankami zakładu poprawczego, zakładu karnego, wychowawca w jednostce penitencjarnej czy terapeuta, który prowadzi pracę resocjalizacyjną w ośrodku 
wychowawczym dla osób niedostosowanych społecznie - w wyniku różnych działań zawodowych, aktywizacyjnych nabiera doświadczenia (Beno 1996). Mówimy, że jest to doświadczenie uczące zarówno dla osób, które wykonują te funkcje, jak i dla odbiorców ich zachowania.

Ten trzeci moment doświadczenia własnego jest cechą, która wyznacza pojęcie inteligencji subiektywnej (Andrzejuk 1998). Oczywiście można powiedzieć, że każda z osób tworzących jakąkolwiek grupę jest wyposażona w kompetencje na poziomie inteligencji subiektywnej poprzez odpowiedni stopień profesjonalizmu, który będzie bardzo zróżnicowany: wypowiedzi profesora kryminologii będą się przecież różnić od wypowiedzi premiera na ten sam temat czy też od wypowiedzi polityka, który mówi, że każdego, kto popełni przestępstwo, trzeba kierować do zakładu karnego. Jednak elementy ocen, reakcji czy elementy postaw tworzą się również poprzez oglądanie telewizji czy czytanie prasy. Wielu ludzi podejmuje się praktyk kulturowych, religijnych, obyczajowych - jest to taki rodzaj uczestnictwa, który pozwala na głębszy, bardziej dynamiczny ogląd otaczającej rzeczywistości, i także te postawy będą się zmieniać. Wielu ludzi wreszcie działa na rzecz innych w różnych organizacjach filantropijnych czy charytatywnych, im również będzie przyporządkowany pewien przymiot doświadczenia subiektywnego.

Zatem na skali inteligencji subiektywnej różnicujemy się, ale jednocześnie trzeba powiedzieć, że jest to myślenie na najniższym poziomie, czyli mamy do czynienia z pewną werbalizacją stanu faktycznego, z pokazaniem zjawiska, wykazaniem tylko jego kształtu istnienia, natomiast nie budujemy jego treści, nie poznajemy jego istoty (Galewicz 1988).

Zawsze mówię studentom - żeby ich rozbawić - że człowiek jest na poziomie małpy, jeżeli mamy do czynienia z ocenianiem na poziomie subiektywnym. Jest to myślenie przodka, czyli małpy, która ma chodzić po chodniku, merdać ogonem i artykułować zjawiska społeczne poprzez wyposażenie siebie w te przymioty, o których wspomniałem, ale wszystko dokonuje się w kategoriach ocen własnych, doświadczenia własnego i pewnego prawdopodobieństwa, sądów na poziomie własnej kompetencji.

Jeżeli człowiek chce się rozwijać, to może, lecz nie musi, podnieść się na drugi poziom - interpretowania, kim jest i co powinien robić. Jest to element tzw. inteligencji obiektywnej (Jaworski 2001). Inteligencja obiektywna to nie jest ogląd zjawiska, tylko próba odpowiedzi na pytanie, skąd to się bierze, to próba zinterpretowania czynników, zwrócenia uwagi na czynniki etiologiczne. Jeżeli np. uczeń nakłada nauczycielowi wiadro na głowę, o czym dowiedzieliśmy się z mediów, musimy zastanowić się, co było przyczyną takiego zachowania, jakie czynniki je warunkują. Tak samo jest w przypadku przestępcy. Prowadząc wykłady w różnych instytutach, spotykam się z szeregiem specjalistów, którzy zajmują się kwestiami 
z zakresu kryminologii porównawczej, realizują programy naprawcze, zajmują się właśnie wyjaśnianiem czynników warunkujących sprawcze zachowanie człowieka, który popełnia zbrodnię.

Kiedy chcemy podyskutować na poziomie inteligencji obiektywnej na temat przestępcy, przestępczości i zjawisk kontroli społecznej, czyli polityki ograniczania tego zjawiska, to musimy sięgać do wyjaśnienia przyczyn (Levinas 1984). Musimy te przyczyny definiować nie na zasadzie, że „mnie się tak wydaje”, „to wynika z mojego doświadczenia", lecz należy sięgać do teorii naukowych, czyli krótko mówiąc mamy do czynienia już z kategorią pewnej analizy, która na dodatek musi być analizą wieloczynnikową (Anysz 1995). Analizą na poziomie teorii, która będzie badała przyczyny. Przyczyna jest bowiem zawsze najistotniejszym stanem rzeczy, przyczyna to źródło, to indukcja, to ogól elementów warunkujących powstanie jakiejś postaci zaburzenia psychicznego, niedostosowania społecznego czy przestępczości (Machel 2001). Muszę wywnioskować o tej przyczynie, muszę zobaczyć, czy jest jedna przyczyna, czy jest ich wiele.

\section{DIAGNOZOWANIE SPOŁECZNE A TEORIE NAUKOWE}

Zjawisko integracji społecznej wiąże się z problemem określenia, jakie elementy tkwią w człowieku, a jakie poza nim, jakie czynniki, istotne, gdy musimy wyprowadzać człowieka z roli dewianta w kierunku roli ex-dewianta, znajdują się po stronie osoby, a jakie po stronie grupy, otoczenia, infrastruktury czy ogólnie systemu społecznego (Mariański 1995).

Oprócz wspomnianych czynników i wielopostaciowej analizy tych czynników jako przyczyny musimy na poziomie inteligencji obiektywnej pokazać pewien stopień zaawansowania jakiegoś działania, które jest charakterystyczne dla danej osoby, określić pewien etap, w którym występuje to zjawisko, ponieważ stopień niedostosowania jest różny. Człowiek najpierw ma tylko objawy, potem występuje pierwsze stadium, następnie stadium zaawansowania, które kończy się okresem terminalnym. W związku z tym należy więc także określić stopień zaawansowania czynników, które warunkują chorobę (Steffen 1955).

To wszystko wiąże się z tzw. pojęciem diagnozowania. Zachowanie człowieka powinniśmy umieć wyjaśnić na poziomie przyczyny, a zatem sięgamy do teorii. Jakie powinny być te teorie naukowe? Powinny to być teorie strukturalne, epistemologiczne, teorie dynamiczne, naukowo projektujące, czyli mające pewną perspektywę rozwojową. Te teorie powinny mieć charakter teorii anamnestyczno-katamnestycznej analizy, powinny to być teorie longitudinalne, a także teorie ekologiczne, ponieważ dzisiejszy świat nauki posługuje się pojęciem nowych teorii 
ekologicznych - mamy medycynę ekologiczną, psychologię ekologiczną, pedagogikę ekologiczną (Wolicka 1989).

Owe teorie powinny dysponować różnymi perspektywami myślenia, wśród których powinna się znaleźć perspektywa, która pokaże strukturę zjawiska, jego dynamikę, perspektywa, która wskaże wszystkie objawy i stadia tego zjawiska, perspektywa, która pozwoli prognozować, jak to zjawisko będzie się zmieniało w czasie (Żelazny 1986). Tak należy postępować, jeżeli chcemy wyjaśnić, dlaczego istnieją przestępcy seksualni, co sprawia, że człowiek po wyjściu z zakładu karnego nadal gwałci, gdy chcemy wyjaśnić, dlaczego rozwija się agresja i dewiacja wśród młodzieży, co zrobić, żeby uczeń o wysokim stopniu agresywności uspokoił się, włączył w konstruktywne grupy klasowe czy koleżeńskie i funkcjonował poprawnie (Maslow 1986). I to jest proces jego integracji do tej grupy klasowej czy szkolnej. Natomiast jeżeli w tym przedziale socjalizacji został skierowany do zakładu poprawczego czy innej placówki wychowawczej lub resocjalizacyjnej, a po jego wyjściu zastanawiamy się, czy może włączyć się w struktury społeczne, to mówimy już o reintegracji, czyli o ponownej próbie pozytywnej, właściwej jego socjalizacji (Nowak 1999).

Wspomniane przeze mnie teorie powinny bazować na badaniach empirycznych. Pierwszym wymiarem badań są analizy anamnestyczno-katamnestyczne. Dotychczas zaś posługujemy się badaniami na małych grupach, które przeprowadzane są w sposób statyczny, czyli w jakimś czasie analizujemy np. całą populację kilku klas szkolnych i zastanawiamy się nad badaniem poziomu ryzyka, strachu czy poziomu lęku tych uczniów. Robimy analizy matematyczne, wychodzą nam korelacje statystyczne, ale to tzw. śmietnik intelektualny, niemający nic wspólnego $\mathrm{z}$ inteligencją obiektywną, ponieważ nie jest to poprawna analiza w sensie warsztatu metodologicznego. Nie jest ona w stanie wyjaśnić zjawiska od strony struktury, dynamiki, pewnej złożoności i prognozy, gdyż rejestruje jedynie fakt i ten fakt odtwarza. A zatem nie jest w stanie wyjaśnić, dlaczego tak jest i jak powinno być (Tarnowski 1982).

Z ubolewaniem stwierdzam jako kryminolog, że z szeregu badań dotyczących zjawisk społecznych, choć dysponują one poprawną techniką i technologią opisu, nie za wiele jeszcze wynika. Jeżeli chcemy, żeby z tej inżynierii społecznej wynikała próba zmiany otoczenia, jeżeli chcemy się dowiedzieć, co zrobić, żeby człowiek miał szansę się zintegrować po kryzysie, po stanach opresyjnych, po różnych stanach niepowodzenia, po świadomym wyłączeniu się z grupy, to musimy umieć wyjaśnić to zjawisko, właściwie je przeanalizować. Moglibyśmy to zrobić, gdybyśmy dysponowali informacjami czy danymi na poziomie badań strukturalnych, a tymi badaniami są badania anamnestyczno-katamnestyczne (Bałandynowicz 2006). 
Anamneza jest to badanie czegoś, co poprzedza stan choroby, stan niepowodzenia, stan kryzysu, stan odmienności, stan dewiacji, stan przestępczości człowieka. Mamy się zajmować reintegracją, a zatem każdy przychodzi na świat jako istota dobra, bo przecież nie rodzą się ludzie źli, nie ma żadnego genu ani systemu genetycznego osoby niepoprawnej, agresywnej, niebezpiecznej, takiej która ma komuś szkodzić. Nauka wyklucza tego rodzaju historie (Sztompka 1971). W związku z tym można powiedzieć, że jest jakiś czas, w którym człowiek funkcjonuje jako prawie święty, bo dobry.

Osoba przechodzi przez różne okresy, fazy, cykle życia, trzeba patrzeć na człowieka poprzez pryzmat etapów jego rozwoju. Psychologia rozwojowa wymienia następujące fazy w życiu jednostki: fazę dzieciństwa, adolescencji młodzieńczej, wczesnej dojrzałości, późnej dojrzałości, wczesnej dorosłości, późnej dorosłości (Rodziński 1998). Psychologia rozwojowa człowieka zwraca także szczególną uwagę na okres najwcześniejszy, okres fazy oralnej, analnej czy genitalno-maciczno-edypalnej lub wczesnej lateracji (utajenia). Okres od 0 do 13 lat (wczesny okres dojrzewania) jest bardzo istotny, tu się wszystko zaczyna. Już dziecko 1-, 2- czy 3-dniowe reaguje na wszystkie bodźce otoczenia, nie mówi, bo nie może mówić, jednak reaguje na to, co mówimy i jak mówimy, czy mówimy na zasadzie miłości, czy konieczności, czy jesteśmy obok, czy powierzamy obowiązki rodzicielskie osobom trzecim, a sami jesteśmy poza sferą naszego oddziaływania na dziecko. To wszystko jest rejestrowane: czy jesteśmy w stanie wskazującym na spożycie alkoholu i artykułujemy swoje stany emocjonalno-uczuciowe. To wszystko jest rejestrowane w centralnym układzie nerwowym i odzywa się jako constans, jeżeli temu towarzyszy tzw. opresja, frustracja, stan przykry w kolejnych etapach życia (Pytka 1995).

W związku z tym anamneza jest próbą odpowiedzi na pytanie, jak długo trwa okres poprzedzający manifestację pewnych oznak niedostosowania społecznego, naruszania norm czy wartości społecznych. Jako kryminolog uważam, że anamneza rozpoczyna się od zapytania byłego przestępcy lub niedostosowanego społecznie, czy jego poród był kleszczowy i jak wyglądał okres dzieciństwa i adolescencji młodzieńczej, ponieważ okres uwalniania się spod opieki rodziny jest najistotniejszym okresem dla jego dalszej socjalizacji (Morris 1956).

Anamneza jest to czas, kiedy nie występują objawy choroby, jeśli nazwiemy chorobę pewnym okresem sytuacji trudnej z racji zawinienia czy pewnych czynników otoczenia społecznego. Ten okres może sięgać od 0-10 lat do 20 lat w zależności od tego, jaki jest wpływ czynników toksycznych na jednostkę bądź kiedy sama jednostka kształtuje pewne toksyczne zachowania. Do czasu kiedy to nie następuje, mówimy, że jest to okres anamnezy.

Trzeba pamiętać, że jeżeli zajmujemy się osobą, to tym bardziej powinniśmy analizować tę początkową fazę okresu adolescencji dziecięcej i młodzieńczej. 
Psychologia rozwojowa osoby stanowi, że trzeba zapytać, jaki człowiek jest i jak był kształtowany w poszczególnych fazach rozwojowych. A specjaliści podkreślają, że okres od 0 do 3 lat to najważniejszy okres w życiu każdego z nas. Należy więc wiedzieć, jak przebiegał u tych, którzy wchodzą w role społeczne negatywne z punktu widzenia interesu grupowego (Legowicz 1986).

Katamneza to okres, w którym zaczęły powstawać pierwsze objawy oraz choroba, czyli wejście w rolę odmieńca, dewianta czy przestępcy. Badanie katamnestyczne nie może być statyczne. Nie mogę wybrać odmieńców czy dewiantów i badać tej grupy tylko w tym czasie, kiedy podejmuję analizę. Jest to znowu nieporozumienie intelektualne, ponieważ badania mogą być poprawne $\mathrm{w}$ sensie struktury metodologicznej, ale niepoprawne w sensie inteligencji obiektywnej, bo nie są w stanie doprowadzić do wykształcenia struktury obrazu tej rzeczywistości, przestrzeni, dynamiki i prognozy społecznej (Kalka 1994).

Katamneza w jakościowych badaniach powinna trwać nie mniej niż pięć lat, a nawet ten okres powinien być zwielokrotniony, czyli minimum to pięć lat obserwowania człowieka w klasie, w ognisku szkolno-wychowawczym, w domu starców, w domu opieki społecznej czy w jakiejkolwiek instytucji, w której się znalazł, żebyśmy mogli wyprowadzić określone wnioski, co ta instytucja poczyniła dla osoby i czy ona po opuszczeniu tej instytucji może się reintegrować społecznie.

Jeszcze lepiej, jeżeli mamy możliwość przedłużania tych badań na kolejne pięć lat. Ja np. w latach 80 rozpocząłem badanie 2000 recydywistów. Badam ich do dziś - to prawie już 30-letnia katamneza. Wspomniałem, że trzech kryminologów w świecie stosuje badania wielokatamnestyczne, w metametodologii nazywamy je badaniami longitudinalnymi. Czyli drugim przymiotem analizy katamnestycznej jest przejście z analizy anamnestycznej na badania wielokatamnestyczne (Bałandynowicz 1991).

Badania, które umożliwiają pokazanie, jak jednostka funkcjonuje nie tylko w zakładzie, ale także jak działa we wszystkich fazach rozwoju, nazywamy badaniami biograficznymi, życiorysowymi i wtedy mówimy o inteligencji obiektywnej, ponieważ obiektywizują one te wszystkie powtarzające się stany, które analizujemy do uogólnienia. Są to jedyne badania, które nie zawierają subiektywizmu, ponieważ nie można nakreślać sobie życiorysu. Życiorys jest taki, jaki jest, a suma tych życiorysów poprzez analizę naukową pozwala na pozyskanie wiarygodnych danych, które mówią o obiektywnym stanie, dzięki czemu można w tej analizie wielokatamnestycznej uzyskać odpowiedzi na postawione problemy.

Jak wspomniałem, w roku 1980 rozpocząłem badania na próbie 2000 recydywistów, badam ich do dzisiaj, ale z tej próbki pozostało raptem już tylko 168 skazanych. Jest to nieduża grupa, ponieważ recydywiści mają styl życia, który polega na bardzo szybkim realizowaniu potrzeb i manifestowaniu postaw, które nie mają 
nic wspólnego z jakąkolwiek higieną psychiczną i społeczną, w związku z czym średnia życia recydywisty w Polsce nie przekracza 46 lat (Bałandynowicz 1993).

Kiedy mówimy o inteligencji obiektywnej, to należy wskazać na elementy analizy anamnestyczno-katamnestycznej, które stanowią podstawę formułowania wielu teorii. $Z$ tych powodów jestem autorem teorii wychowania do wolności, teorii probacji, teorii zhumanizowanego odwetu dla kary, teorii reintegracji społecznej, czyli adaptowania człowieka ze struktur zakładowych w struktury otwarte. Inteligencja obiektywna jest to proces myślowy, suma twierdzeń, zweryfikowanych hipotez, wyprowadzanych z wieloletnich badań, które pozwalają formułować teorie naukowe. Dlatego zdefiniowałem teorię czy grupę teorii, które pomogą zinterpretować, dlaczego istnieje dany stan rzeczy, czy tak powinno być i w jakim zakresie należy działać, żeby zmienić niekorzystne stany po stronie sprawcy czy pewnych struktur społecznych (Bałandynowicz 1996).

Z moich badań wynika, że pierwsze przestępstwo popełniane jest w okresie 9-10 lat. Popełniają je osoby, które dokonują pierwszych przestępstw w fazie przed dojrzałością społeczną, kiedy nie mamy jeszcze do czynienia z ukształtowaną świadomością społeczną, bardzo prymitywny jest też element inteligencji człowieka, natomiast okoliczności zewnętrzne, społeczne decydują o tym, że osoba podejmuje się zachowania przestępczego i popełnia go w przedziale tych lat. Chcę podkreślić, że jest to najbardziej niebezpieczny wiek, brak interwencji w tym okresie sprawia, że te osoby będą stanowiły 75 proc. wszystkich przestępców (tamże).

Jeżeli ktoś na poważnie chciałby się zajmować problemem profilaktyki kryminalnej i późniejszym okresem reintegracji społecznej, to okres do 10 roku życia powinien być dla niego najistotniejszym okresem zaświadczającym o rozwoju człowieka. Badając tę fazę, można się zastanawiać nad strukturą zjawiska, jego dynamiką, prognozą, tak by nie dopuszczać do symptomów, żeby nie nastąpił rozwój zachowań toksycznych, niebezpiecznych dla sprawcy. Ponadto badania powinny uwzględnić podejście ekologiczne, bowiem mamy do czynienia nie tylko z perspektywą analizy mikro- i makrospołecznej i empirycznego oglądu danego stanu rzeczy, ale także z próbą ustalenia wieloczynnikowych przesłanek warunkujących przebieg zjawiska (Fatyga 1999).

Kontynuując zagadnienia dotyczące drugiej płaszczyzny na poziomie przedzałożeniowego myślenia aksjologicznego dotyczącego zagadnień reintegracji społecznej, wymienić należy podejście empiryczne badanego stanu rzeczy, mówiące, iż winno ono mieć wymiar analizy dwufazowej. Zwróciłem uwagę na fazę anamnezy i fazę katamnezy. Wskazałem także, że najlepiej tę katamnezę przedłużać na okresy, fazy i cykle rozwoju człowieka, aby mieć pełen obraz tzw. działań indukcyjnych pozwalających projektować i wyjaśniać, dlaczego tak się dzieje w kolej- 
nych fazach, w ramach tzw. systemu instytucjonalnego, i jak może funkcjonować człowiek po opuszczeniu systemu instytucjonalnego na wolności (Chałas 2003).

Należy wyjaśnić, jakie wartości ma taka analiza. Dzisiaj słyszymy - na poziomie inteligencji subiektywnej - że najlepiej, aby kara była surowa. Analizy katamnestyczne pokazują zaś, że więźniowie na przykład w mojej próbie badawczej 3/4 życia przesiedzieli w systemie izolacyjnym, poddawani izolacji pejoratywnej. Można więc zapytać, jaka jest skuteczność tych działań, skoro - odliczając okresy pobytu na wolności, przerwy w odbywanej karze, zliczając i komasując wymiar bezwzględnego czasu spędzonego w izolacji - można powiedzieć, że okres życia więźnia $\mathrm{w} 75$ proc. jest to czas poddawany pejoratywnej izolacji, a po 16 skazaniu okresy na wolności są to przerwy, które mierzą się w dniach, nawet nie tygodniach czy miesiącach (Bałandynowicz 2002). A jednocześnie na poziomie inteligencji subiektywnej twierdzi się, iż należy „wsadzać, wsadzać” i rozbudowywać system penitencjarny, ponieważ jest to jedyna możliwość, iż po opuszczeniu miejsc izolacji osoba wejdzie ponownie w przestrzeń otwartej wolności. Niestety proces jest zaprzeczeniem tego typu myślenia i osoba będzie stałym klientem systemu izolacyjno-dyscyplinarnego, skoro 75 proc. okresu życia spędza w instytucjach izolacyjnych (Bałandynowicz 2002). Także jeżeli mamy do czynienia np. z zachowaniami patologicznymi w postaci nadmiernego spożywania alkoholu, analiza katamnezy kilkudziesięcioletniej pokazuje, że w sensie eliminowania różnych stanów dewiacyjnych, w tym nałogu alkoholowego, uzależnień od narkomanii czy zaburzeń seksualnych bądź zaburzeń psychicznych, system izolacyjny jest całkowicie niewydolny, ponieważ nie tworzy możliwości wyjścia z choroby (Scheller 1986). Człowiek poddawany jest przez cały czas różnym programom autorskim dotyczącym zmiany zachowania w warunkach systemu izolacyjnego. Tymczasem stopień alkoholizowania czy stopień uzależnienia od narkotyków, który wpływa na zachowania i postawy człowieka, tworząc postać zachowania dewiacyjnego, dla recydywy wynosi powyżej 80 proc (Świda 1979). Recydywiści, których badam od 30 lat, poddawani byli wielu programom leczenia odwykowego, trwającym od kilku do kilkunastu tygodni, a niektórzy korzystali z kilkumiesięcznego programu leczenia odwykowego. Jednak jest to system niewydolny nie tylko $\mathrm{z}$ racji krótkiego czasu oddziaływania za pomocą specjalistycznych metod, które powinny tworzyć pewną alternatywę dla alkoholu, ale również dlatego że ten element nie może się poddać zmianie ani racjonalnej kontroli w warunkach zamknięcia (Bałandynowicz 2002). I o tym trzeba wyraźnie powiedzieć: integrować człowieka do systemu społecznego, czyli prowadzić jego reintegrację, można wtedy, gdy wyjdzie z choroby, z opresji, z trudności, gdy wyjdzie ze stanu, który dotknięty jest procesami dysfunkcji (Witek 1988). 
W istocie stwarzamy tylko pozory, wymyślając różnorodne, nawet te specjalistyczne i drogie programy terapeutyczne, które mają świadczyć o tym, że ów proces jest poddawany ciągłej humanizacji. Jednak humanizacja to nade wszystko działanie racjonalne - nie powinno być tylko odruchem serca, ale także elementem pomocy, kompetencji, zmiany i kontroli społecznej (Zaleski 1991). Dlatego twierdzę, że gdyby politycy i prawnicy, którzy tworzą prawo normatywne z zakresu tzw. systemu pomocy postpenitencjarnej czy pomocy następczej dla nieletnich, młodocianych, zechcieli na to zwrócić uwagę, to należałoby na poziomie badań anamnestyczno-katamnestycznych tworzyć szeroki system tzw. serwisu probacyjnego otwartego, w ramach którego można byłoby prowadzić proces zmiany zachowania, integracji do warunków wolnościowych, a potem można byłoby wprowadzać tych ludzi w świat struktur wolnościowych.

Od 30 lat publikuję teorię probacji. Jak obserwuję - nawet na poziomie interpretacji terminu przekraczamy często granice myślenia obiektywnego, bo podkładamy różne treści pod nazwę tegoż właśnie systemu. Reintegracja to typowy przykład, kiedy działania w ramach systemu izolacyjnego przesuwamy na rzecz systemu otwarcia.

\section{FUNKCJONALNOŚĆ STRUKTUR SPOŁECZNYCH}

Wieloletnie badania pokazują, jak bardzo ważny jest pierwszy okres rozwoju człowieka. Należy odnotować, że najistotniejszą grupą, która odpowiada za proces dysfunkcji, dezintegracji, za proces wadliwego i odmiennego funkcjonowania człowieka w przestrzeni społecznej, jest rodzina, dlatego tutaj odniosę się tylko - kiedy mówię o myśleniu obiektywnym - do teorii longitudinalnych, czyli badań wieloletnich dotyczących rodziny (Adamiec 1983). Dzisiaj na rynku krajowym prowadzone są badania płaskie, które mają charakter opisu statusu osobowego, struktury rodziny, pozycji małżonków, atmosfery, postaw rodzicielskich. Wiele takich danych można byłoby jeszcze wymieniać. Tymczasem one na dobrą sprawę tylko opisują, a nie tłumaczą zjawiska w kontekście tego, jak powinno być i co zrobić, żeby doprowadzać do sytuacji integracji i żebyśmy później nie tworzyli pewnych zastępczych formuł w ramach polityki społecznej (Bielecki, Nowicki 1991). Chcę przywołać tutaj teorie Loebera, (Loeber, Stouthamer-Loeber 1996), Snydera (Snyder, Patterson 2004), Anderssona (Andersson 2002), Pattersona (Patterson, Snyder 2004) i wskazać cztery paradygmaty w ramach reintegracji społecznej, tj. paradygmat konfliktu, paradygmat przemocy, paradygmat dewiacji i paradygmat śmierci.

Otóż na poziomie rodziny kształtujemy siebie jako człowieka, jako wartość, albo bardzo często siebie eliminujemy jako człowieka czy jako wartość w przyszłym 
świecie. Należy więc stwierdzić, że o tym, czy człowiek będzie się poprawnie poruszał w przestrzeni społecznej, decyduje przede wszystkim dom rodzinny (Bielicki 1995). Powinniśmy uciec przed wiktymizacją i przerzucaniem odpowiedzialności na jakiekolwiek inne struktury społeczne. Człowiek przychodzi na świat w rodzinie i w rodzinie umiera. Albo się utożsamia $\mathrm{z}$ rodziną, albo funkcjonuje poza nią (Wojciszke 2003). W związku z tym ten element jest najistotniejszy w rozwoju każdej jednostki, a przecież mamy zajmować się jednostkami, które są odmienne, dewiatywne czy patologiczne - po to żeby je w procesie reintegracji włączać w struktury społeczne.

Te cztery paradygmaty tłumaczą nam istotę rzeczy i istotę przyszłej polityki społecznej, która powinna zwracać uwagę na określone wymiary profilaktyki: profilaktyki prawa, profilaktyki terapeutycznej, profilaktyki rodzinnej - bo inaczej będziemy stwarzać pewną formułę zachowań trudnych, patologicznych dla młodych ludzi. Badania, o których wspomniałem, pokazują, że wiele czynników warunkuje te zachowania trudne. Pierwszy z paradygmatów, paradygmat konfliktu, polega na stwarzaniu sytuacji, w której człowiek uczy się, że nie jest podmiotem, lecz przedmiotem. Tak więc to, czy będziemy mieć niską samoocenę, poczucie niskiej wartości, poczucie braku posiadania bezpieczeństwa, uznania, akceptacji, wyłącznie zależy od tego, czy w domu jesteśmy traktowani na poziomie podmiotu czy instrumentu, przedmiotu (Suchodolski 1959). Pierwszym obiektem oddziaływania na dziecko jest matka oraz ojciec. Okres tego oddziaływania jest różny, może trwać nawet kilkanaście lat - do okresu pełnoletniości czy też do okresu usamodzielnienia się. W Polsce ten okres się przedłuża ze względu na brak mieszkania. Na Zachodzie uwolnienie się od władzy rodzicielskiej następuje znacznie szybciej dzięki temu, że jest łatwiejszy dostęp do mieszkań, a także do korzystnych kredytów mieszkaniowych. Tymczasem proces podmiotowego traktowania człowieka jest bardzo ważny, ponieważ człowiek staje się istotą autonomiczną. Kiedy uwalnia się spod władzy rodziców i wchodzi do pierwszych grup społecznych, jego socjalizacja odbywa się już w wymiarze społecznym, istotne jest więc, czy stanowi podmiot mocno zdezintegrowany ze względu na niską samoocenę i samoakceptację społeczną. Chcę wyraźnie powiedzieć, że paradygmat konfliktu polega na tym, że człowiek jest spychany w domu do roli środka czy narzędzia, a nie osoby, z którą się rozmawia, którą traktuje się po partnersku, której zleca się zadania, która będzie odpowiedzialna za różne wybory i którą się szanuje ze względu na jej potrzeby, określające tzw. świat wewnętrzny człowieka (Blanquart 1979). O tym, czy rodzic potrafi to zauważyć i realizować, decydują postawy rodzicielskie. Przywołując tutaj teorie Maccobiego (Maccoby, Martin 2003) i Martina czy też inne teorie w zakresie postaw rodzicielskich, np. M. Ziemskiej (Ziemska 1997), należy stwierdzić, że przeważają wtedy postawy autorytarne, lekceważenia czy pobłażania, 
a więc takie, które charakteryzują się tym, że człowiek jest sterowalny zawsze z zewnątrz, że dziecku narzuca się cele, utożsamia się je z pewną rolą, że nie może dokonywać własnych wyborów, ma ograniczone wewnętrzne potrzeby czy zainteresowania. Tym samym poddawane jest tresurze, pewnemu przymusowi czy nawet bardzo wyrafinowanemu, zewnętrznemu, profesjonalnemu realizowaniu tego, co sobie założyła matka czy ojciec (Błasik 2002). Jest to uprzedmiotowienie jednostki, które w wymiarze paradygmatu konfliktu jest mierzalne. Jeżeli tego rodzaju symptomy, działania są postrzegane, jest to już element, który będzie decydował w sposób bardzo wyraźny o przyszłości dziecka. Takie dzieci będą bardziej skłonne do wchodzenia w pewne role dewiacyjne, a także większość z nich może realizować wrogie zachowania, czyli nawet zachowania przestępcze (Sobczak 2009). Jeżeli wiemy o tym, trzeba wskazywać na profilaktykę, prewencję w tym zakresie, na pewne oddziaływania w tej pierwszej fazie rozwoju jednostki do momentu samouwolnienia się od opieki rodziców (może to być różny okres). Trzeba zaznaczyć, że nawet gdy ktoś korzysta z przedłużonego okresu pobytu w domu ze względu na brak mieszkania, to w sensie psychicznym może się uwolnić z domu całkowicie - ze względu na te cztery paradygmaty. Przypomnieć tu należy klasyfikację wielowymiarowości człowieka prof. K. Dąbrowskiego, który wymienia świat psychiczny, duchowy, fizyczny, społeczny człowieka (Dąbrowski 1972). Osoba, która przechodzi wczesną dojrzałość w wieku 13 lat, zaczyna w sensie psychologii klinicznej postrzegać innych, czyli grupę. Jeżeli rodzice będą postępować tak, jak to opisują wspomniane cztery paradygmaty, dziecko będzie w domu obecne tylko fizycznie, natomiast jego świat wrażliwości, uczuć, emocji, zainteresowań, świat postaw, aktywności będzie się znajdował poza domem. Jeśli młody człowiek jest coraz bardziej ograniczany, to po prostu wychodzi z domu na ulicę. A nie jest to miejsce właściwe dla niego w tym okresie życia (Bocheński 1993).

Paradygmat przemocy obecny jest w badaniach Loebera, Stouthamer-Loeber, Anderssona, Pattersona, tych badaczy, którzy pokazują, jak we wczesnym dzieciństwie ten element dysfunkcjonalności domu decyduje o okresie adolescencji młodzieńczej i przyszłej dorosłości, wskazują też na przyszłe zależności statystyczne i powiązanie tego paradygmatu z rolą dewianta i przyszłą rolą przestępczą (Krokiewicz 2000). Przemoc to nie tylko stosowanie elementów surowej dyscypliny, negatywna władza rodzicielska, ale przemoc to przede wszystkim lekceważenie jednostki i naruszanie jej autonomii, czyli naruszanie jej godności. Każdy człowiek, nawet ten najmłodszy, jest podmiotem ze względu na swoją konstrukcję, a zgodnie z teorią psychologii personalistycznej każdy człowiek powinien być wartością i być traktowany jako wartość (Ratzinger 1996). Wtedy proces jego socjalizacji będzie przebiegał prawidłowo. Jeżeli natomiast spotyka się z zachowaniami przemocowymi: czy to fizycznie, czy słownie, czy na poziomie atmosfery, postaw rodzicielskich, 
czy też w postaci braku zainteresowania dzieckiem w domu, to mamy do czynienia z paradygmatem przemocy, ponieważ takie działania naruszają jego autonomię, jego godność (Pytka 1997). Młody człowiek doświadczający przemocy będzie się starał uwolnić od rodziców, ponieważ zacznie szukać alternatywy, miejsca, gdzie będzie autonomiczny, gdzie będzie czuł się osobą zauważalną, akceptowalną, mogącą realizować pewne potrzeby czy określone zainteresowania (Eliade 1974).

Trzeci paradygmat, który - jak wynika z wieloletnich badań - jest dużym wyzwaniem w procesie integracji i późniejszym procesie reintegracji, to paradygmat dewiacji, chodzi tu zwłaszcza o dewiację twardą: alkohol, prostytucję, przestępczość, bicie, karcenie (Gajda 1992). W badaniach longitudinalnych należy zwrócić uwagę na tzw. dewiację miękką, dla mnie jako kryminologa bardziej niepokojącą. Moim zdaniem siła tej dewiacji jest bardziej niszcząca, bo o ile można znaleźć pewne remedium na zachowania patologiczne spowodowane alkoholem, na przestępczość, o tyle nie można znaleźć takiego środka na dewiację miękką - trudno z tego stanu wyjść, powiedziałbym, że nie jest to tylko stan traumy, ale stan politraumy, czyli będzie się on utrzymywać bardzo długo (Heller 2004). Mianowicie dewiacja miękka jest to element np. uczenia w środowisku rodzinnym relatywizmu moralnego czy etycznego, kiedy pozwalamy młodemu człowiekowi na nieograniczoną wolność wyboru norm i zachowań. Na przykład rodzic przychodzi z pracy i opowiada, co z niej przyniósł, jednemu udało się wynieść papier toaletowy, drugiemu pieniądze czy 5 kilo wędliny, w zależności od tego, jakie role społeczne pełni. Inny opowiada, że wręczył komuś kopertę za zaliczone egzaminy. Dziecko to wszystko widzi, obserwuje. Obserwuje w kategoriach usług, kupowania wszelkich kompetencji i kupowania pewnych zadań i sposobów wyboru określonych stanów rzeczy (Kalka 1994). To jest właśnie dewiacja miękka, polegająca na naśladownictwie elementów zła w kategoriach etyki i moralności. W polskiej rzeczywistości dewiacja miękka jest to aprobata dla drobnej przestępczości dzieci i młodych ludzi - co potwierdzają badania longitudinalne. Rejestry sądowe i oficjalne statystyki pokazują, że liczba drobnych kradzieży dokonanych przez dzieci bądź pobicia rówieśników w strukturze przestępczości nieletnich kształtują się mniej więcej na poziomie kilkunastu procent. Natomiast jeśli będziemy analizować to zjawisko, kiedy te same osoby będą dorosłe i zapytamy je o pobicia i kradzieże w okresie wcześniejszym, okazuje się, że te czyny popełnia 60-70 proc. wszystkich badanych (Ładyga 1975). Tego rodzaju sytuacja, związana z naruszeniem dobra, mienia rówieśników, ich zdrowia, odbywa się za aprobatą rodziców; rodzice są zadowoleni, że dziecko jest zaradne, zapobiegliwe, wyrażają opinie pozytywne na temat rozwiązywania przez nie problemów, radzenia sobie z trudnościami. Dziecko czuje, że ma przyzwolenie na takie działania, np. na demonstrowanie i używanie siły, byleby się nie dało złapać Okazuje się, że ok. 70 proc. młodych ludzi w przedziale od 10 do 16 lat 
wdaje się w bójki bądź kradnie (Sobczak 1996). Rodzice są zadowoleni, że dziecko ma środki na obóz, na wakacje, że syn wyjeżdża z dziewczyną. Oczywiście nie chcą dopuścić do świadomości, że dochody te są z nielegalnego źródła. Osoby te nie muszą podejmować zatem legalnego zatrudnienia, gdyż istnieje na to zachowanie przyzwolenie rodziców. Mamy wówczas wyraźnie do czynienia z paradygmatem dewiacji środowiska familijnego jako paradygmatem akceptacji pewnych zachowań kolidujących z normami moralnymi i etycznymi. Można postawić tezę, że młody człowiek będzie szanował prawo nie dlatego, że będzie spotykał się z nakazami bądź zakazami, ale dlatego że nie było dewiacji miękkiej w domu (Pospiszyl 2008). Nie ma żadnej zastępczej etyki, moralności, obyczajowości. To dom rodzinny kształtuje postawy społeczne młodzieży (Freud 1976).

Kolejny paradygmat to paradygmat śmierci, który w pedagogice społecznej nosi także określenie paradygmatu zniszczenia. Mówimy tu o rozwodach, śmierci rodziców, bezrobociu, pauperyzacji, wykluczeniu, o tych wszystkich elementach, które świadczą o braku pomocowości i braku uczciwości ze strony otoczenia, ponieważ każda rodzina jest grupą społeczną, częścią społeczeństwa. Każdy człowiek jest autonomiczny, ale jego autonomia budowana jest zależnie od tego, jak ludzie go odbierają. Także rodzina nie zawsze jest autonomiczna, pomimo że powinna taka być. Jednak w sytuacji, kiedy zachodzą takie zjawiska, jak rozwód, choroba, śmierć, wykluczenie, to zauważamy, że mamy do czynienia z brakiem wsparcia, pomocy, uczciwości czy opieki. W przypadku młodych ludzi, którzy funkcjonują w klimacie społecznym wyznaczonym przez ten paradygmat, mamy do czynienia z zachowaniami, które będą odbiegały w dużej części od normy, będą to zachowania dewiatywne (Derrika 2002). W roku 2010 odnotowano 80 tys. rozwodów, a zatem małżeństwo ustaje między dwojgiem ludzi, tak więc rozwody dotyczą 160 tys. osób, z czego 90 proc. rozwodzących się małżonków ma dzieci. W związku z tym mamy przy jednym zjawisku rozwodu problem kilkuset tysięcy osób. Tak wielka jest populacja osób, która na poziomie dezintegracji życia psychicznego, uczuciowo-emocjonalnego może mieć pewne ograniczenia w zakresie własnego świata duchowego, psychicznego, społecznego, a także fizycznego. To jeden taki wskaźnik, który powinien demonstrować paradygmat zniszczenia jako bardzo ważny w kategoriach przyszłej polityki reintegracji i budowania pozytywnego modelu oddziaływania (Gogacz 1992).

Wspomniałem, że badania empiryczne są bardzo ważne, jeśli chce się dojść do określonych teorii, choć czasami nie trzeba wykonywać badań, żeby zrozumieć istotę jakiejś rzeczy. Ale jeżeli wyciągamy pewne wnioski na poziomie inteligencji obiektywnej, to mogą one pochodzić wyłącznie z takich badań, które będą obiektywizowały rzecz, które tę rzecz na zasadzie obiektywizacji będą uznawać za powszechną, stałą, powtarzalną i weryfikowalną. Natomiast czasami możemy myślą, 
pewnym abstrakcyjnym sposobem interpretowania logicznego dochodzić czy przybliżać się do prawdy - chcę podkreślić, że nie dochodzić, lecz przybliżać się do prawdy (Woroniecki 1961). W tej rzeczywistości bowiem, w której się zajmujemy problemem reintegracji człowieka, czyli ukazywaniem jego wielowymiarowości, możliwości, jego kształtowania w warunkach życia społecznego, dobrą nauką jest taka, która formułuje twierdzenia probabilistyczne, czyli względne, a nie absolutnej prawdy, ponieważ nigdy do końca nie da się poznać istoty społecznej, jaką jest człowiek, możemy tylko starać się próbować ją poznać i taką drogą obiektywną, powszechną przybliżać się do prawdziwej wiedzy (Tyszka 1997).

Potrzebne są tu teorie, które przełamują wymiar czasu i przestrzeni, czyli takie, które mają dość długi rodowód. Nie chcę przez to powiedzieć, że teorie nowe, aktualne, nie są naukowe czy sensowne. Jeśli mamy wyjaśnić jakieś zjawisko, to można to zrobić poprzez konstruowanie diagnozy tegoż zjawiska i wówczas sięgamy do teorii, która musi być ponadczasowa. Podobnie jest $\mathrm{z}$ lekiem, który należy podać pacjentowi. W ulotce do leku czytamy, że został wyprodukowany w tym roku czy nawet pięć lat temu. Przeprowadzono próby na kilkuset tysiącach pacjentów i mamy do czynienia z takimi a takimi pożądanymi stanami rzeczy, natomiast w większości przypadków lek powoduje stany niepożądane. Jeżeli więc człowiek bez konsultacji chciałby zażyć taki lek, to musiałby go po zakupieniu od razu wyrzucić. Natomiast jeżeli weźmiemy lekarstwo na zaburzone stany psychiczne, którym leczono np. 50 lat temu i dzisiaj, to uzyskamy nieco inną treść wspomnianej ulotki - mianowicie że ten lek został wyprodukowany dawno, że został przetestowany na znacznej liczbie ludzi, jednocześnie otrzymujemy ewidentnie pożądane stany rzeczy, a tylko fragmentarycznie odnotowuje się pojedyncze przypadki działania toksycznego, które mogą wywołać niekorzystne objawy.

Analogicznie jest $\mathrm{z}$ teoriami, tzn. dobre teorie w praktyce to takie, które istnieją i sprawdzają się od dawna (Szutrowa 1989). Ponadto muszą być to teorie interdyscyplinarne, czyli tworzone na pograniczu wielu nauk, to teorie, które tworzą wymiar myślenia obiektywnego, nie monokierunkowe: wywodzone z języka, z metodologii i z poprawności technologicznej jednej dziedziny wiedzy, kiedy korzystamy z tych samych obszarów języka, przedmiotu, podmiotu i metodologii drugiej, trzeciej, czwartej dziedziny wiedzy. Teorie z pogranicza prawa, filozofii, psychologii, pedagogiki, kryminologii, psychiatrii, medycyny - to teorie interdyscyplinarne. Na obrzeżach tych wielu nauk, wielu dziedzin, kiedy będziemy realizować przedmiot Człowiek i reintegracja społeczna, wtedy właśnie spróbujemy wyjaśnić to, co jest, a właściwie jak powinno być, gdyż jesteśmy w stanie tylko przybliżyć się do rzeczywistej prawdy (Rybicki 1997).

Jest jeszcze kolejna grupa teorii: teorie holistyczne i teorie przestrzenne, które nazywam ekologicznymi. Po pierwsze, trzeba ukazywać osobę holistycznie - kim 
ona jest, a także holistycznie pokazywać, jakie czynniki decydują o jej zachowaniu: czy czynniki, które są w osobie czy na zewnątrz, czy w osobie i na zewnątrz, a wtedy, mówiąc o holizmie, trzeba traktować to jako strukturalną całość. Holizm i ekologia to pokazanie człowieka w przestrzeni, w środowisku, pokazanie człowieka jako podmiotu i zintegrowanej całości w przestrzeni społecznej (Oleś 1984). W związku z tym można stwierdzić, że te kryteria spełnia teoria ekologiczna Bronfenbrennera (według której człowiek powinien być traktowany jako jednostka holistyczna i znajdująca się w przestrzeni społecznej ku integracji społecznej). Ta teoria pokazuje przede wszystkim holizm jednostki, czyli jedność osoby od strony struktur, które ją stanowią, jak struktura korpusu, psychiczna, duchowa i struktura społeczna. Natomiast z drugiej strony mamy do czynienia z pewną przestrzenią społeczną i tutaj Bronfenbrenner zwraca uwagę na czynniki mikrospołeczne, mezospołeczne, egzospołeczne i makrospołeczne.

Teoria przestrzeni społecznej Bronfenbrennera zakłada istnienie czterech rodzajów czynników. Czynnik mikro to czynnik, który wskazuje na podstawowy obiekt oddziaływania na człowieka, czyli na rodzinę (Bronfenbrenner 1998). Wadliwa rodzina to ta, która rządzi się wspomnianymi paradygmatami, oddziałującymi na cały proces rozwoju człowieka. Czynnik mezo stanowią inne grupy. Z punktu widzenia psychologii społecznej młody człowiek zaczyna postrzegać inne środowiska poza domem, postrzega rówieśnika. Dziewczyna dostrzega koleżankę, dostrzega chłopaka, zaczyna się nimi interesować. Ta formuła nawiązywania kontaktu partnerskiego, tworzenia pierwszych interakcji koleżeńskich, czy to są osoby tej samej płci, czy odmiennej, czas trwania tych interakcji, ich charakter (grupy zabawy czy określonych zadań) - wszystko to będzie miało istotny wpływ na dalszy rozwój młodego człowieka (Längle 2003). Drugi wymiar grupowej socjalizacji w układzie mezo stanowi szkoła, w której pojawić się może problem agresji, agresywności, symetryczności czy asymetryczności. W grupie klasowej sposób funkcjonowania dziecka w szkole będzie decydował o przyszłych sukcesach czy niepowodzeniach. Zatem należy badać, jaka jest komunikacja pomiędzy rówieśnikami, jakie są wzajemne interakcje, czy ograniczają się do pewnych działań formalnych, czy są merytoryczne, jak wykształca się system norm, wartości, zachowań, pewnych stałych postaw w tym układzie, a także jak organizowany jest czas wolny (Ingarden 1989). Jeżeli młody człowiek nie ma możliwości zaspokajania swoich potrzeb, bo jego dom jest średnio zamożny bądź biedny, może dołączyć do grupy zastępczej, która przejmie funkcje wypełniania czasu wolnego (Hojnicka-Bezwińska 1991). Są to grupy podwórkowe, grupy uliczne, a nawet grupy chuligańskie, które mogą zamienić się w bandy czy grupy przestępcze. To jest problem interakcjonizmu na poziomie mezosystemu społecznego aktywności człowieka, na poziomie zaspokajania swoich potrzeb, rozwijania zainteresowań, kiedy funkcji 
tych nie spełnia dom bądź szkoła (Gilson 1994). Zawsze musi zaistnieć jakiś czynnik, który kompensuje i wyrównuje „ja” realne $\mathrm{z}$ „ja” idealnym, który eliminuje brak poczucia bezpieczeństwa, uznania i akceptacji jednostki. W dużej części będzie to realizować struktura nieformalna w społeczności otwartej (Bulla 1987).

Wspomnieć wreszcie należy czynnik egzosystemu, który wiąże się w koncepcji Bronfenbrennera $\mathrm{z}$ tzw. otoczeniem społecznym. Możemy wymienić tu prawo, a raczej pewien system rozwiązań proponowanych przez to prawo, infrastrukturę sieci usług. Krótko mówiąc, chodzi o to, jak wygląda zorganizowane społeczeństwo: czy istnieje tzw. wspólny mianownik, co świadczymy na rzecz innych, czy oddajemy jakieś swoje dobra, swój czas, sferę swojej wolności na rzecz tych innych, którzy z tego powinni korzystać, ponieważ sami nie mogą wykształcić lub nie mogą posiąść możliwości uczestniczenia w świecie kultury, sztuki, w świecie aktywności kulturowo-cywilizacyjnej (Ekman, Davidson 1998).

Koncepcja Brofenbrennera to koncepcja holistycznego człowieka. Każda osoba ma duszę, każda jednostka chce być szczęśliwa, chce być zauważona albo pragnie być znaczącym podmiotem w grupie, w której funkcjonuje. Otóż proces reintegracji społecznej powiedzie się, o ile w układzie egzosystemu, o którym wspomina Bronfenbrenner, będą istniały takie rozwiązania określone $\mathrm{w}$ prawie, $\mathrm{w}$ polityce społecznej, w szeroko pojętych strukturach sieci usług, które będzie można przyporządkować do tzw. społeczeństwa normatywnego, a nie do społeczeństwa anomijnego (Kant 1988). Społeczeństwo anomijne to takie, w którym każdy działa sam dla siebie, każdy jest twórcą samego siebie, w którym traktuje się swoich członków anonimowo, a aktywność na rzecz innych realizowana jest jedynie przez wymiar płacenia podatków na rzecz skarbu państwa, bez jakichkolwiek elementów oddawania usług czy czynienia ograniczeń na rzecz tych, którzy są gorsi, nie posiadają tego, co ja posiadam. W związku z tym ja właśnie w tym świecie społecznym jestem odsunięty, odizolowany, nie próbuję się integrować z grupami społecznymi (Konopczyński 1996). Społeczeństwo normatywne zaś to społeczeństwo, które jest humanitarne, czyli wie o tym, że dzielenie się, pomaganie, jest elementem koniecznym i niezbędnym dla prawidłowego funkcjonowania jednostki, grupy i społeczeństwa jako całości (Krąpiec 1994; Kieszkowska 2012).

Z kolei układ makrospołeczny, o którym wspomina Bronfenbrenner, to układ idei, ideologii, światopoglądu, moralności i etyki, czyli tych wyznaczników kształtujących świadomość człowieka, które pozwolą mu się prawidłowo zasymilować. Młody człowiek pewne idee ogranicza na początku do marzeń, do oczekiwań, później wraz z rozwojem, w poszczególnych etapach i cyklach życia, stają się one elementem światopoglądu, jakości i obrazu życia, celów życia, aż wreszcie powinny sięgnąć prawa i etyki, która stanowi wymiar najwyższy (Cackowski 1979). Bronfenbrenner mówi, że holizm to zgodność myśli, idei i światopoglądu, moralności 
i etyki, to zgodność w sensie prawa i etyki, kiedy człowiek nie jest rozdarty wewnętrznie, kiedy nie podlega sądom relatywistycznym ze względu na podmiot oceniający, kiedy sama jednostka potrafi się wszechstronnie rozwijać ze względu na zgodność tych wszystkich wyznaczników makrosystemu. Natomiast toksyczny jest taki układ społeczny, w którym występują rozbieżności między prawem a etyką, w którym etyka nie będzie akceptowana lub włączana w system światopoglądu czy idei człowieka (Mazur 2008). Człowiek w procesie socjalizacji winien mieć możliwość budowania swojej wielowymiarowości - ale wielowymiarowości w holizmie, w jedności, a nie jej tworzenia w chaosie i we wzajemnej eliminacji (Nawroczyński 1974).

Otóż jeżeli w układzie tych wszystkich cech, desygnatów i wyznaczników makrosystemu sam człowiek będzie postrzegał różnice w zakresie socjalizacji w domu, szkole, klubie, partii politycznej lub gdziekolwiek indziej, jeżeli będzie miał możliwość przystosowywania się do wybiórczych elementów światopoglądu, ideologii czy etyki, to wówczas ta osoba staje się instrumentem szeroko pojętej polityki społecznej, poddaje się łatwo sterowaniu zewnętrznemu, a nawet głębokiej manipulacji ze strony tychże podmiotów (Rotter 1966). Natomiast jeżeli człowiek będzie funkcjonował w makrosystemie, którego wszystkie elementy są ze sobą zintegrowane, to wówczas możemy powiedzieć, że to on sam będzie decydować o sobie, on sam będzie twórcą samego siebie i on sam będzie wykorzystywać uczące doświadczenia samego siebie (Sobczak 2004). Jeszcze raz powtórzę te trzy elementy, bo będę wielokrotnie do nich powracać. Podkreślają one, że człowiek jest podmiotem - w myśl koncepcji M. Starczewskiej - przynależy do modelu sokratejskiego, który zakłada, że człowiek jest wartością, doświadczenia osoby są uczące, wreszcie że człowiek jest twórcą samego siebie (Styczeń, Merecki 1996). Będzie to możliwe tylko w sytuacji pełnej zgodności norm i przekonań, które osobie wpoiły rodzina, szkoła, inne grupy społeczne. Będzie się to przekładać na ideologie i światopogląd, z którego będzie korzystała w życiu społecznym, w trakcie swojej aktywności kulturowej, stale podkreślając sens norm etycznych. W takim przypadku tworzy się rzeczywiście wymiar człowieka holistycznego (Vernant 1996).

\section{REINTEGRACJA WSPARTA NA WARTOŚCIACH}

Trzecia płaszczyzna myślenia to myślenie na poziomie aksjologii. Jeżeli ta wspomniana przeze mnie małpa, która merda ogonem na poziomie inteligencji subiektywnej, chce się cywilizować, to zakłada okrycie, wychodzi na ulicę i wtedy myśli na poziomie inteligencji obiektywnej. Jeżeli natomiast chce się stać człowiekiem, musi sięgnąć do aksjologii, żeby zgubić te wszystkie wyznaczniki czy atrybuty 
długiego ogona lub wystających palców. Człowiek do sposobu swojego myślenia na temat bytów, otaczającej rzeczywistości, zjawiska, które analizujemy - czyli reintegracji społecznej - powinien przyłożyć warstwę analizy wspartej na wartościach (Ziółkowski 1997).

Jeżeli przedkładamy zjawisko reintegracji na poziomie etyki, to na początku należy stwierdzić, że mamy do czynienia z trzema grupami podmiotów, które są adresatami tej etyki. Pierwszym z nich jest sprawca jakiegoś zachowania niedozwolonego, bo reintegracja to jest przecież powrót człowieka, który szkodzi, krzywdzi innych, powrót człowieka, który jest w opresji, w stanie konfliktu społecznego. Typowy przykład to osoba, którą chcemy zresocjalizować, żeby następnie poddać ją procesowi integracji do grup społecznych. Drugim podmiotem jest ofiara. Ofiara jest jakby przedstawicielem szerszych grup społecznych - mamy do czynienia ze społeczeństwem jako całością (May 1998). Należy zaznaczyć, że tym drugim podmiotem jest właśnie ofiara w powiązaniu ze społeczeństwem. Trzeci podmiot stosunku integracyjnego czy reintegracyjnego to mianowicie: kultura i cywilizacja. Nie uważam zatem, że klasyczny stosunek reintegracyjny dotyczy człowieka i społeczeństwa. Klasyczny stosunek reintegracji osoby to stosunek, który badamy na poziomie relacyjności podmiotowej trzech elementów: sprawcy, ofiary w powiązaniu ze społeczeństwem oraz kultury i cywilizacji (Malewska 1962). Ponadto te trzy podmioty powinny stanowić jedność, to znaczy - jakby powiedział pedagog społeczny - tworzymy tzw. perspektywę pedagogiczną. Musimy bowiem zbudować taką rzeczywistość społeczną po stronie grupy, grup, po stronie różnych układów społecznych, w której nie będziemy dzielić i nie będziemy tworzyć odrębności statusowej, lecz będziemy starali się stwarzać takie modele i takie systemy reintegracji czy integracji społecznej, w których sprawca, ofiara i społeczeństwo, kultura i cywilizacja będą stanowić jedność. Uważam, że tak powinno być, bo dzięki temu można zbudować procedurę działań i strategię postępowania, ponieważ oparta jest ona na założeniu, które będzie determinowało wszystkie elementy tych oddziaływań (Rorty 2007).

Wszystkie wyznaczniki myślenia przedzałożeniowego dlatego są tak określane, że stanowią naturalny czynnik strukturalizujący procedurę jako proces, co ma wpływ na jego elementy jako ciąg zorganizowanego działania ludzkiego w oparciu o zasoby, potencjały, metody, techniki i środki postępowania (Sawicki 1996).

Trzeba wyraźnie określić definicję wymiaru etycznego w odniesieniu do wspomnianych trzech grup podmiotowych: po stronie sprawcy jest to tzw. tożsamość osobowa, po stronie ofiary i społeczeństwa - tożsamość społeczna, a po stronie kultury i cywilizacji - tożsamość kulturowa (Sośnicki 1933). Czyli tworzymy wymiar etyczny, który w sposób ostry i wyraźny definiuje proces reintegracji społecznej. Należy teraz podać wyznaczniki tożsamości osobowej, solidaryzmu społecznego, 
który jest rozbieżny z tożsamością społeczną, a także wyznaczniki pojęcia tożsamości kulturowej (Tatarkiewicz 1990).

Po stronie sprawcy tożsamość osobowa to system czterech wartości, który powinien być wpisany w układ makrosystemu społecznego, według teorii Bronfenbrennera. Trzeba bowiem pamiętać, że integracja oznacza włączenie osoby do społeczeństwa, zatem należy wiedzieć, jaka powinna ona być w stosunku do społeczeństwa, co społeczeństwo powinno jej dać, co osoba powinna posiadać, żeby móc wejść do społeczeństwa. W aksjologii, w etyce mówimy o czterech wartościach cząstkowych, które definiujemy jako: 1) wolność wewnętrzną, 2) prawo do wyboru, 3) odpowiedzialność jednostki, 4) prawo do zaciągania zobowiązań (Urban 2007).

Jeżeli chodzi o drugą wartość centrową, tzw. tożsamość społeczną czy solidaryzm społeczny, to możemy powiedzieć, iż jest to system społeczny trzech wartości, które są holistycznie ze sobą powiązane, a są nimi: uczciwość, pomocowość i efektywność, czyli koherencja działania (Frączek, Kofta 1976).

Natomiast tożsamość kulturową tworzą dwie wartości: akceptacja i zrozumienie człowieka (Gogacz 1985).

Powinniśmy zadbać o to, żeby w tzw. działaniach sprawczych, w prawie, w otoczeniu, normach i obyczajowości, w działaniu ideologizującym, światopoglądzie - zwracać uwagę na podstawową, fundamentalną wartość etyczną, to jest tożsamość człowieka (Kotarbiński 1970).

Sięgamy wówczas na poziomie inteligencji obiektywnej do teorii, $w$ tym wypad$\mathrm{ku}$ - psychoanalizy, teorii przystosowania społecznego, teorii systemów, a także odwołujemy się do pewnego kierunku myślenia egzystencjalno-humanistycznego (Gorlach 2003). A ponieważ w grę wchodzi człowiek, najlepiej sięgnąć do psychologii personalistycznej. Warto tu wspomnieć o rozprawie Jana Pawła II pt. Osoba i czyn. Dowiadujemy się z niej o tych wszystkich wartościach, które budują nasze człowieczeństwo i stanowią o wartości, jaką jest każdy człowiek, oraz świat wolności wewnętrznej, świat potrzeb (Czapów 1962). W procesie resocjalizacji jednostki trzeba pamiętać o tym, że najistotniejsza jest sprawa kształtowania właściwego świata wolności wewnętrznej, a w sytuacji, kiedy ten świat wolności wewnętrznej jest ograniczony, należy doprowadzać do odblokowania naturalnych potrzeb i zainteresowań jednostki (Suchodolski 1976).

W psychologii społecznej nazywa się ten proces zjawiskiem deprywacji potrzeb. Czasami mówimy o wtórnej dewiacji, o psychogenezie zachowania sprawcy, tzn. ujawnionych stanach potrzeb podstawowych, potrzeb wyższego rzędu lub zainteresowaniach, które nie mogły być zrealizowane. A blokada tych wewnętrznych stanów rzeczy prowadzi do wadliwej socjalizacji. Wtedy należy rozpocząć resocjalizację i stwarzać szansę na kreowanie stanów wewnętrznych pożądanych przez osobę, bo tylko jednostka, która będzie dysponowała zintegrowaną osobowością, 
może być włączona do świata wolnego (Wojciszke 1986). A tymczasem jak kształtujemy świat wolności wewnętrznej skazanego np. w zakładzie karnym? Reglamentujemy korespondencje, paczki, widzenia, pracę, to wszystko, co nie powinno być ograniczone. Reglamentujemy nawet mycie się pod prysznicem. Doprowadzamy do sytuacji absurdalnej, bo w procesie socjalizacji wkraczamy w świat wolności człowieka, ograniczając jego naturalne potrzeby (Znaniecki 2001).

Drugim elementem tożsamości człowieka w wymiarze sprawcy jest prawo do wyboru. Jeżeli człowiek nie ma wyboru, działa nielogicznie, jeżeli więc mamy mówić o systemie, musimy budować układ logiczny, w którym prawo, ideologia, praktyka postępowania dają możliwości wyboru. Wspomniałem o kastracji chemicznej, o której wypowiadał się premier. Każdy sprawca, u którego stwierdzamy zaburzenie psychiczne na poziomie seksualnym, może dokonać kastracji, ale jest to tzw. kastracja farmakologiczna, dokonywana tylko za zgodą skazanego. Bez alternatywy, bez możliwości wyboru, stosujemy wyłącznie kary hańbiące, a takie kary były wykonywane w średniowieczu (Machel 2003). W XXI wieku nie powinno być żadnych kar okaleczających człowieka, kar hańbiących, odbierających prawo do wyboru i godności ludzkiej. Kiedy wyjeżdżam na wykłady do Skandynawii, spotykam podczas różnych hospitacji zakładów karnych zabójców, sprawców nieraz bardzo drastycznych i barbarzyńskich zbrodni. Nawet ich po pewnym czasie zapytuje się, czy chcą się poprawić. Należy sprzeciwić się resocjalizacji zadekretowanej w kodeksie karnym, jak to się dzieje w Polsce. Resocjalizacja powinna stanowić odpowiedź człowieka na pytanie, czy się chce zmienić (Lotze 1910). Trzeba mu przedstawić propozycję i ofertę zmiany. Do wspomnianych zbrodniarzy po trzech latach przychodzi nauczyciel więzienny, który się nimi opiekuje, i pyta, czy chcą się zresocjalizować, bo któryś z nich jest np. dewiantem seksualnym czy ma zaburzenia osobowości, jest psychopatą reaktywnym czy człowiekiem o rozproszonej inteligencji, czyli ma niskie z punktu widzenia rozumu rozeznanie tego, co czyni. W ten sposób podkreśla się podmiotowość i tożsamość osobową sprawcy. Ja dokonuję wyboru, on dokonuje wyboru, a efektem dokonywanych wyborów jest podpisanie kontraktu. Skazany podpisuje kontrakt. Jest to umowa, swobodne oświadczenie woli. Wolę wyraża podmiot, a nie przedmiot. W wyniku umowy jest zobowiązany do określonych działań, zdobywa pewne prawa i zobowiązania, musi świadczyć pewne usługi (Dąbrowska, Wojciechowska-Charlak 1997). W tym wypadku jako dewiant godzi się np. na tzw. kastrację farmakologiczną, czyli zażywa leki, najczęściej jedno lekarstwo, które jest dozowane w określonym czasie poprzez system kontroli zewnętrznej, która musi wywołać kontrolę wewnętrzną (Dana 1966). Kontrolę zewnętrzną stanowi tzw. monitoring elektroniczny, a kontrola wewnętrzna są to określone zmiany neurochirurgiczne, immunologiczne, psychiczne w osobie na skutek działania leku i ćwiczeń socjoterapeutycznych (Marks, 
Engels 1961). I to wszystko stanowi propozycję, realizowane jest prawo do wyboru. Jest to działanie etyczne, bowiem wkraczamy z interwencją, ale jednocześnie dajemy prawo do wybierania, nie narzucamy swojej woli innej osobie.

Trzecim elementem, o którym wspomniałem, jest odpowiedzialność. Człowiek musi być odpowiedzialny za swoje wybory. A jaka jest odpowiedzialność człowieka, który zabił i nie płaci stałej renty na rzecz ofiary, skazanego, który ukradł i nie zwraca zagarniętego mienia? W swojej teorii probacji na ten temat piszę od 30 lat, jednak politycy tego nie czytają i dlatego mamy takie prawo. Byłoby zupełnie inaczej, gdyby sprawca był odpowiedzialny za swoje czyny. Proponuję, aby skazany pracował tak długo, aż odpracuje zagarnięte mienie, zamiast go kierować na koszt podatnika do zakładu karnego. Jeżeli zabije człowieka bądź go trwale okaleczy, powinien zapłacić odszkodowanie. Prawo jest taką dziedziną, która pozwala na wykonywanie restytucji, czyli przywrócenie stanu poprzedniego. Instytucją prawną w przypadku zabójstwa bądź powstania szkody jest instytucja odszkodowania. W związku z tym nic nie stoi na przeszkodzie, żeby formuła odszkodowania, w postaci np. stałej renty na rzecz dzieci, które zostały osierocone, była formułą podmiotowości sprawcy, tożsamości w sensie etyki, czyli odpowiedzialności (Linton 1975).

Ponadto, jak mówił Jan Paweł II, istnieje możliwość zaciągania zobowiązań. Podmiot, czyli człowiek, może sam siebie ograniczyć, czyli sam może zaciągnąć pewne zobowiązanie (Dąbrowski 1974). To jest najbardziej wyraźny i dostrzegalny przymiot władzy człowieka: kiedy decyduje, kiedy może rozkazywać, kiedy sam zaciąga zobowiązanie. Powrócę tu do wspomnianego wcześniej przykładu: jeżeli ktoś zabił, może być nie tylko odpowiedzialny za swój czyn, ale także zaciągać zobowiązanie na rzecz ofiary. Przebywając w zakładzie karnym, więzień może wziąć kredyt na naukę, ukończyć studia, znaleźć i wykonywać pracę podczas odbywania kary, a także płacić stałą rentę, np. na rzecz dzieci swojej ofiary. Podejmuje się zobowiązania, więc istnieje powinność ustalenia zakładu pracy, żeby znaleźć mu takie miejsce zatrudnienia, aby ta renta była systematycznie wypłacana, ponieważ sprawca zdecydował się na systematyczne świadczenie w wyniku swojego czynu. Należy stwierdzić, że inaczej wygląda pozycja skazanego, kiedy reprezentuje go w poszukiwaniu zatrudnienia zakład karny, a inaczej, kiedy robi to urząd pracy. Utrzymywanie w Polsce mitu, stereotypu, że zamykanie w zakładzie karnym jest jedyną formą traktowania podmiotowego sprawcy, jest zupełnym nieporozumieniem.

Drugą wartością fundamentalną jest tożsamość społeczna, a dotyczy ona ofiary i społeczeństwa. Prawo powinno kształtować świadomość społeczną ukierunkowaną na odpowiedzialność, uczciwość, pomocowość i użyteczność (Malewski 1962). Uczciwość społeczna oznacza realne stwarzanie szans komuś, kogo chcemy poddać zmianie, np. przestępcy czy nieletniemu sprawcy. Z kolei pomocowości 
nie należy rozumieć jako pomocy materialnej, a stwarzanie możliwości, aby osoba swój problem umiała rozwiązać samodzielnie. A my jesteśmy przyzwyczajeni do systemu rozdawiennictwa, co jest niczym innym, jak ratownictwem, które nie ma nic wspólnego z pomaganiem i właściwie rozumianą pomocą (Nancy 1997). Natomiast użyteczność to efektywne rozwiązanie problemu społecznego, bowiem należy próbować tego poprzez system instytucjonalny.

Trzecim elementem perspektywy pedagogicznej zorganizowanego działania integracyjnego jest tożsamość kulturowa, w której ramach wyróżniliśmy dwie wartości: akceptację i zrozumienie. W trakcie diagnozowania psychospołecznego nie możemy jedynie konstruować opinii i diagnoz jako sumy zaburzonej osobowości, stopnia nieprzystosowania społecznego, defektów czy ilości toksyn, lecz musimy się nauczyć, że człowiek jest sumą zła i dobra. Musimy zaakceptować jednostkę taką, jaka ona jest i wyeliminować wszelkie oceny subiektywne w stosunku do czynu, zdarzenia, które spowodowało, że trzeba jednostkę włączyć do systemu ponownie, kierując się mechanizmami wyjaśniającymi i umożliwiającymi modyfikację w kierunku zachowania pożądanego (Rogers 1959). Istotne jest także zrozumienie, tzn. uznanie prawa do odmienności, prawa do inności, prawa do decydowania o samym sobie (Dembińska-Siury 1991).

\section{PODSUMOWANIE}

Diagnoza sytuacji społecznej dzieci i młodzieży wykazuje występowanie co najmniej trzech niekorzystnych zjawisk warunkujących przebieg procesu ich socjalizacji. Jest to, po pierwsze, zjawisko depresji jednostkowej i depresji grupowej sprowadzającej się do utraty przez jednostki kontroli nad swoim codziennym środowiskiem oraz utraty społecznej wartości w następstwie braku poczucia przydatności, autonomii i niezależności. Wysoki stopień niezaspokojenia potrzeb podstawowych oraz rozwojowych doprowadza młodych ludzi do pauperyzacji, wykluczenia i rezygnacji z aspiracji i własnych celów życia.

Kolejne zjawisko niekorzystnie kształtujące społeczne wzrastanie jednostki to socjopatia, rozumiana jako forma egoizmu i obojętności na los człowieka ze strony innych osób. Pojawia się ona w atmosferze nadmiernego współzawodnictwa i zaspokajania potrzeb nawet za cenę skrzywdzenia innych i skrajnej obojętności, braku empatii na ich problemy egzystencjalne i wychowawcze. Towarzyszy procesowi socjopatii społecznej zjawisko nadmiernej komercjalizacji i karierowiczostwa. Osoba staje się przedmiotem, a nie podmiotem, gubi swoją odmienność i staje się nieodpowiedzialna za swoje wybory w procesie socjalizacji. 
Nieprawidłowy mezosystem społeczny generuje zjawisko wiktymizacji, które osłabia wszelką autoodpowiedzialność jednostki, oskarżającej innych za patologie swych zachowań. Jest to tendencja do oczyszczania siebie $\mathrm{z}$ win poprzez atakowanie otoczenia, kreowanie nieufności i urazów wobec najbliższych obiektów wychowawczych, uważanych za odpowiedzialne za własne frustracje i niemożliwość zaspokajania potrzeb.

Badania longitudinalne dostarczają wiedzy, iż elementy życia rodzinnego pozostają w bliskiej zależności z zachowaniami agresywnymi, w tym przestępczymi, u dzieci i młodych ludzi. Zwłaszcza studia empiryczne Lobera i Stouthamer-Loeber dały podstawę do sformułowania czterech paradygmatów jako źródeł wadliwej socjalizacji. Są nimi: paradygmat lekceważenia, konfliktu, zachowań i postaw dewiacyjnych oraz zniszczenia. Paradygmat lekceważenia oznacza, że rodzice nie poświęcają dostatecznie dużo czasu swoim dzieciom i są nieświadomi jakichkolwiek problemów, z którymi mogą spotkać się one poza domem. Rodzice pozostają obojętni na sytuacje dewiacyjne zachowań dzieci, nie kontrolują ich czasu wolnego i nie znają otoczenia rówieśniczego, które dostarcza im akceptacji i potrzeby uznania.

Paradygmat konfliktu przejawia się w rodzinnych interakcjach rodziców i dzieci i sprowadza się do preferowania agresywnych wzorów zachowań wzajemnych. Ten typ komunikacji doprowadza do eskalacji niechęci, konfliktu i braku uznania. W następstwie tego typu postępowania wyzwala się przemoc fizyczna, która całkowicie eliminuje możliwość współpracy i uszanowania autonomii.

Rodzice mogą ulegać różnym dewiacjom, gdyż legitymują się kryminalną przeszłością lub przejawiają patologiczne postawy zmierzające do wywierania wpływu na dzieci w tym samym kierunku. Dzieci uczą się wzorów dewiacyjnych zachowań od rodziców poprzez bezpośredni przekaz tego typu wyborów lub ich akceptowanie.

Paradygmat zniszczenia uzewnętrznia się w sytuacjach, gdy rodziny narażone są na szkodliwe działanie czynników zewnętrznych, takich jak: bezrobocie, bieda, wykluczenie społeczne, trwała choroba lub kalectwo, rozwód, separacja lub śmierć. Następstwem tych traumatyzujących sytuacji jest wyzwalanie się konfliktów rodzinnych na podłożu niewłaściwych kontaktów emocjonalnych. Zewnętrzne stresory niszczą harmonię związków familijnych, obniżają próg irytacji, skutkiem czego wzrasta prawdopodobieństwo agresji wśród członków rodziny.

Analizy empiryczne Snydera i Pattersona, dotyczące rodzinnych interakcji opisywanych w kategoriach dyscypliny, rodzicielstwa pozytywnego, kontrolowania zachowań dzieci poza domem oraz rozwiązywania problemów i konfliktów, wskazują na bezpośredni ich wpływ na funkcjonowanie w dewiacyjnych rolach młodych ludzi. Snyder i Patterson rozwinęli dwufazowy model zachowania dewiacyjnego u dzieci. Pierwszy etap definiuje związek rodzinny - lekceważenie dzieci we 
wczesnych fazach procesu socjalizacji prowadzące do nieodpowiedniej społecznej adaptacji, która z kolei prowadzi do braku dyscypliny i nieposłuszeństwa. Nieposłuszne dziecko jest zazwyczaj odrzucone przez osoby z najbliższego środowiska i tym samym wykazuje tendencje do włączania się do grup rówieśniczych o cechach patologicznych lub wręcz kryminalnych.

Dotychczasowy stan wiedzy na temat socjalizacji osób przekonuje, iż analiza funkcjonowania dzieci i rodziców w środowisku, w którym rzeczywiście żyją, dostarcza danych najbardziej diagnostycznych i pomocowych w określaniu strategii postępowania korygującego wadliwe interakcje pomiędzy członkami wspólnot familijnych. W świetle pedagogiki i psychologii model Bronfenbrennera byłby wskazany do ustalenia na poziomie mikro-, mezo-, egzo- i makrozespołu czynników odpowiedzialnych za dysfunkcjonalny przebieg socjalizacji dziecka, określając jednocześnie etap i fazę tego procesu.

\section{LITERATURA}

Abramowski E. (1986). Idee społeczne kooperatyzmu. W: E. Abramowski (red.). Rzeczpospolita przyjaciót. Wybór pism społecznych i politycznych. Wyd. PAX, Warszawa.

Adamiec M. (1983). Działanie, wartość, sens - zarys systemu pojęć. „Przegląd Psychologiczny", nr 1 (26).

Allport G.W. (1985). The historical background of social psychology. W: G. Lindzey, E. Aronson (ed.). Handbook of social psychology, vol. I. Randon Hause. New York. Andersson B. (2002). Family Support and Development. Department of Education, Stockholm College of Education, s. 47 i n.

Andrzejuk A. (1998). Słownik terminów, św. Tomasz z Akwinu Suma Teologiczna, t. 35. Wyd. Navo oraz Katolicki Ośrodek Wyd. „Veritas”, Warszawa-Londyn.

Anysz W. (1995). Wartość młodego pokolenia $w$ dobie transformacji ustrojowej Polski. Studium teoretyczno-empiryczne. Wyd. WSP, Częstochowa.

Bałandynowicz A. (2006). Probacja. Resocjalizacja z udziałem społeczeństwa. Prawo i Praktyka Gospodarcza, Warszawa.

Bałandynowicz A. (1991). Ludzie bez szans. Studium adaptacji społecznej recydywistów, Wyd. Uniwersytetu Warszawskiego, Warszawa, s. 165 i n.

Bałandynowicz A. (2002). Probacja. System sprawiedliwego karania, Wyd. C.F. Müller. Lex Utilis, Warszawa, s. 61, 206, 217 i n.

Bałandynowicz A. (1996). Probacja. Wychowanie do wolności. Wyd. „Primum”, Warszawa, s. 89. 
Bałandynowicz A. (1996). Style postępowania $z$ recydywistami w warunkach probacji. Wyd. Uniwersytetu Warszawskiego, Warszawa, s. 126 i n.

Bałandynowicz A. (1993). Nieudany powroty. Wyd. Uniwersytetu Warszawskiego, Warszawa, s. 28 i n.

Beno J.A. (1996). Pedagogika. Tłum. Z. Zalewski, J. Ślepowroński. Wyd. Sióstr Loretanek, Warszawa.

Bielecki J., Nowicki W. (red.) (1991). Studia z psychologii. Badania nad zmianami osobowości młodzieży męskiej i żeńskiej poddawanej intensywnemu oddziaływaniu katolickiej formacji religijnej. Wyd. ATK, Warszawa.

Bielicki E. (1995). Młodociani przestępcy, ich wartości i orientacja wartościująca. Wyd. WSP, Bydgoszcz.

Blanquart P. (1979). Atheisme et structuralisme. W: Des chretiens interrogent l'atheisme, t. II, cz. I: L'atheisme dans la philosophie contemporaine. PUF, Paris.

Błasik A. (2002). Młodzież - świat wartości. Wyd. Ignatianum, Kraków.

Bocheński J.M. (1993). Współczesne metody myślenia. Wyd. W drodze. Poznań.

Bronfenbrenner K. (1998). Lewinian Space and Ecological Substancje, „Journal of Social Issues", nr 33, s. 215-217.

Bulla B. (1987). Spostrzeganie hierarchii wartości rodziców przez młodzież a jej własna hierarchia wartości. W: M. John (red.). Orientacja dzieci i młodzieży w sytuacjach społecznych. Wyd. Ossolińskich, Wrocław.

Cackowski Z. (1979). Człowiek jako podmiot działania praktycznego i poznawczego. Wyd. Wiedza i Książka, Warszawa.

Chałas K. (2003). Wychowanie ku wartościom. Elementy teorii i praktyki. Godność, wolność, odpowiedzialność, tolerancja, t. I. Wyd. Jedność, Lublin-Kielce.

Czapów C. (1962). Młodzież i przestępstwa, cz. II. Wyd. Nasza Księgarnia. Warszawa.

Dana R.H. (1966). Foundations of Clinical Psychology. D. Van Nostrade, Princeton.

Dąbrowska T.E., Wojciechowska-Charlak B. (1997). Między praktyka a teoria wychowania. Wyd. UMCS, Lublin.

Dąbrowski K. (1972). Personality Shaping through Positive disintegration. Gryf Publication, Londyn, s. 106 i n.

Dąbrowski K. (1974). Zdrowie psychiczne a wartości ludzkie. Wyd. Polskie Towarzystwo Higieny Psychicznej, Warszawa.

Dembińska-Siury D. (1991). Człowiek odkrywa człowieka. O początku greckiej refleksji moralnej. Wyd. Wiedza Powszechna, Warszawa.

Derrika J. (2002). Marginesy filozofii. Tłum. A. Dziadek, J. Margański, P. Pieniążek. Wyd. KR, Warszawa.

Drwal R.Ł. (1979). Opracowanie kwestionariusza Delta do pomiaru poczucia kontroli. „Studia Psychologiczne” t. 18 (1). 
Ebner F. (2006). Słowo i realność duchowa. Fragmenty pneumatyczne. Tłum. K. Skorupski. Wyd. PAN, Warszawa.

Ekman P., Davidson R.J. (red.) (1998). Natura emocji - podstawowe zagadnienia. Tłum. B. Wojciszke. GWP, Gdańsk.

Eliade M. (1974). Sacrum, mit, historia, Wybór esejów. Tłum. A. Tatarkiewicz. Wyd. PIW, Warszawa.

Fatyga B. (1999). Dzieci z naszej ulicy. Antropologia kultury młodzieżowej. Wyd. ISNS UW, Warszawa.

Frączek A., Kofta M. (1976). Frustracja i stres psychologiczny. W: T. Tomaszewski (red.). Psychologia. PWN, Warszawa.

Freud Z. (1976). Poza zasada przyjemności. Tłum. J. Prokopiuk. PWN, Warszawa.

Gadacz T. (2007). Filozofia Boga XX wieku. Od Lavelle'a do Tischnera. Wyd. WAM, Kraków.

Gadamer H.G. (2002). Idea dobra w dyskusji Latona i Arystotelesa. Tłum. Z. Nerczuk. Wyd. Antyk, Kęty.

Gajda J. (1992). Teoria wartości w filozofii przedplatońskiej. Wyd. Uniwersytet Wrocławski, Wrocław.

Galewicz W. (1988). O fenomenologicznym ujęciu wartości. W: W. Galewicz (red.). Z fenomenologii wartości. Wyd. PAT, Kraków.

Gilson E. (1994). Byt i istota. Tłum. D. Lubicz, J. Nowak. Wyd. PAX, Warszawa.

Gogacz M. (1985). Człowiek i jego relacje. Wyd. ATK, Warszawa.

Gogacz M. (1992). Światopogląd afirmujacy Boga. W: B. Bejze (red.). O filozoficznym poznaniu Boga dziś. W: Studia z filozofii Boga, t. V. Wyd. ATK, Warszawa.

Gorlach K. (2003). Plany i aspiracje a aktualna sytuacja życiowa. W: K. Gorlach, Z. Drąg, Z. Seruga (red.). Młode pokolenie wsi III Rzeczpospolitej. Aspiracje życiowe w przeddzień integracji z Uniq Europejską. Instytut Spraw Publicznych, Warszawa.

Heller M. (2004). Filozofia przyrody. Zarys historii. Wyd. Znak, Kraków.

Hojnicka-Bezwińska T. (1991). Orientacje życiowe młodzieży. Wyd. WSP, Bydgoszcz. Hołyst B. (1999). Kryminologia. PWN, Warszawa.

Ignaczak M. (1986). Wartość rodziców a agresja interpersonalna ich synów. W: A. Frączek (red.). Studia nad uwarunkowaniami i regulacja agresji interpersonalnej. Wyd. Ossolińskich, Wrocław.

Ingarden R. (1989). Wykłady z etyki. PWN, Warszawa.

Jankowski K. (red.) (1981). Psychologia dziecka. Wyd. Czytelnik, Warszawa.

Jaworski S. (2001). Podręczny stownik terminów literackich. Wyd. Universitas, Kraków.

Kaczyńska W. (1992). Przedzałożeniowość myślenia i postępowania pedagogicznego. Wyd. IPSiR UW, Warszawa. 
Kalka K. (1994). Sprawiedliwość i cnoty społeczne według św. Tomasza z Akwinu. Wyd. WSP, Bydgoszcz.

Kalka K. (1994). Sprawiedliwość i cnoty społeczne według św. Tomasza z Akwinu. Wyd. WSP, Bydgoszcz.

Kant I. (1988). Antropologia w ujęciu pragmatycznym. Tłum. W. Buchner. „Pismo Literacko-Artystyczne", nr 4.

Konopczyński M. (1996). Twórcza resocjalizacja. Wybrane metody pomocy dzieciom i młodzieży. Wyd. MEN Editions Spotkania, Warszawa.

Kotarbiński T. (1970). Studia z zakresu filozofii, etyki i nauk społecznych. Wyd. Ossolineum, Wrocław-Warszawa-Kraków-Gdańsk.

Kieszkowska A. (2012). Inkluzyjno-katalaktyczny model reintegracji społecznej skazanych. Konteksty resocjalizacyjne. Oficyna Wydawnicza „Impuls”, Kraków

Krąpiec M.A. (1994). Byt i istota. Dzieła, t. XI. Wyd. KUL, Lublin.

Krokiewicz A. (2000). Sokrates: Etyka Demokrata i hedonizm Arystypa. Wyd. Aletheia, Warszawa.

Längle A. (2003). Analiza egzystencjalna - poszukiwanie zgody na życie. „Psychoterapia”, nr 2 (125).

Legowicz J. (1986). Historia filozofii średniowiecznej Europy zachodniej. Wyd. PAN, Warszawa.

Levinas E. (1984). Sens i etyka. Tłum. S. Cichowicz. „Studia Filozoficzne”, nr 2.

Linton R. (1975). Kulturowe podstawy osobowości. Tłum. A. Jasińska-Kania. PWN, Warszawa.

Loeber R., Stouthamer-Loeber M. (1996). Family Factors as Correlates and Predictors of Juvenile Conduct Problems and Delinguency. W: M. Tonry, V. Morris. „Crime and Justice”, vol. 7, University of Chicago Press, Chicago, s. 112 i n.

Lotze R.H. (1910). Zarys metafizyki: dyktaty podług wykładów. Tłum. A. Stogbaure. Wyd. Księgarnia E. Wende i Sp., Warszawa.

Ładyga M. (1975). Przedmiot i funkcje społeczne filozofii. W: T.M. Jaroszewski (red.). Filozofia marksistowska. PWN, Warszawa.

Maccoby E., Martin J. (2003). Socialization in the Context of the Family: Parent Child - Interaction. W: E. Hetherington. Handbook of Child Psychology, vol. IV. New York, s. 1-102.

Machel H. (2001). Psychospołeczne uwarunkowania pracy resocjalizacyjnej personelu więziennego. Wyd. UG, Gdańsk.

Machel H. (2003). Wiezienie jako instytucja karania i resocjalizacji. Wyd. Arche, Gdańsk.

Malewska A. (1962). Pozytywny i negatywny obrazu własnej osoby a proces podejmowania decyzji. „Studia Socjologiczne”, nr 2

Malewski A. (red.) (1962). Zagadnienia psychologii społecznej. PWN, Warszawa. 
Mariański J. (1995). Młodziė̇ między tradycją i ponowoczesnością. Wartości moralne w świadomości maturzystów. Wyd. KUL, Lublin.

Marks K., Engels F. (1961). Ideologia niemiecka. W: Dzieła, t. III. PWN. Warszawa. Maslow A.H. (1986). W strone psychologii istnienia. Tłum. I. Wyrzykowska. Wyd. PAX, Warszawa.

May R. (1998). Miłość i wola. Tłum. H. i P. Śpiewakowie. Wyd. Rebis, Poznań.

Mazur T. (2008). Kapryśni bogowie Sokratesa. Człowiek i świat wartości w tradycji filozofii zachodniej. Wyd. M. Derewecki, Kęty.

Morris C. (1956). Varieties of Human Values. University of Chicago Press, Chicago.

Nancy J.L. (1997). The Sense of the Word. University of Minnesota Press, Minneapolis.

Nawroczyński B. (1974). Wspótczesne prądy pedagogiczne. Wyd. Nasza Ksiegarnia, Warszawa.

Nowak M. (1999). Postawy pedagogiki otwartej. Wyd. KUL, Lublin.

Oleś P. (1984). Z zagadnień „psychologii wartości”. „Roczniki Filozoficzne”, nr 4 (32).

Patterson G., Snyder J. (2004). Family Support and Development. Department of Education. Stockholm College of Education, s. 89 i n.

Pospiszyl I. (2008). Patologie społeczne. PWN, Warszawa.

Pytka L. (1995). Granice kontroli społecznej i autonomii osobistej młodzieży. „Opieka-Wychowanie-Terapia", nr 1 (21).

Pytka L. (1997). Norma i patologia a tor ludzkiego cierpienia. „Opieka-Wychowanie-Terapia”, nr 2 (30).

Radochoński M. (2000). Osobowość antyspołeczna. Geneza, rozwój i obraz klinicz$n y$. Wyd. WSP, Rzeszów.

Ratzinger J. (1996). Wprowadzenie w chrześcijaństwo. Tłum. Z. Włodkowa. Wyd. WAM, Kraków.

Rodziński W. (1998). Na orbitach wartości. Wyd. KUL, Warszawa.

Rogers C.R. (1959). Toward a theory of creativity. Harper and Bros, New York.

Rorty R. (2007). Wittgenstein i zwrot lingwistyczny. Tłum. D. Łukoszek, Ł. Wiśniewski. „Homo Communicativus”, nr 1 (2).

Rotter J.B. (1966). Generalized Expectancies for Internal Versus External Control of Reinforcement. W: Psychological Monographs, t. 80, vol. 1.

Rybicki R. (1997). Wprowadzenie do pedagogiki chrześcijańskiej. „Biblioteka Niedzieli", nr 46.

Sawicki M. (1996). Hermeneutyka pedagogiczna. Wyd. Naukowe Semper, Warszawa.

Scheller M. (1986). Istota i forma sympatii. Tłum. A. Węgrzecki, Wyd. PAN, Warszawa.

Snyder J.G. Patterson (2004). Family Interaction and Delinguent Behavior. W: H. Quay. Handbook of Juvenile Delinquency, New York, s. 72 i n. 
Sobczak S. (1996). Nie aksjologia lecz filozofia człowieka jako podstawa teleologii wychowania. „Opieka-Wychowanie-Terapia”, nr 4 (28).

Sobczak S. (2004). Aksjologiczne wątki w koncepcji samoświadomości Zbigniewa Zaborowskiego. W: Pytka L., Rudowski T. (red.). Samoświadomość i jakość życia. Perspektywa psychospołeczna. Wyd. Eneteia, Warszawa.

Sobczak S. (2009). Młodzież wobec stopnia akceptacji norm prawnych i moralnych.

W: D. Walczak-Duraj (red.). Wartości i postawy młodzieży polskiej, t. 1. Wyd. UŁ, Łódź.

Sośnicki K. (1933). Podstawy wychowania państwowego. Wyd. Książnica-Atlas, Warszawa.

Steffen W. (1955). Antologia liryki greckiej. Tłum. J. Birkenmajer. Wyd. Ossolińskich, Wrocław.

Styczeń T., Merecki J. (1996). ABC etyki. Wyd. KUL, Lublin.

Suchodolski B. (1959). O pedagogikę na miarę naszych czasów. PWN, Warszawa.

Suchodolski B. (1976). Kim jest człowiek. Wyd. Wiedza Powszechna, Warszawa.

Szołtysek A.E. (1998). Filozofia wychowania. Ontologia. Metafizyka. Antropologia. Aksjologia. Wyd. A. Marszałek, Toruń.

Sztompka P. (1971). Logika analizy funkcjonalnej w socjologii i antropologii społecznej. W: S. Nowak (red.). Metodologiczne problemy teorii socjologicznych. Wyd. UW, Warszawa.

Szutrowa T (red.) (1989). Wybrane zagadnienia testów projekcyjnych. Seria: Biblioteka Psychologa Praktyka, t. III. Wyd. PTP, Warszawa.

Świda H. (red.) (1979). Młodzież a wartości. Wyd. WSiP, Warszawa.

Tarnowski J. (1982). Wprowadzenie do wychowania w rodzinie chrześcijańskiej. W: K. Majdański (red.). Rozwój człowieka rodzinie. Wyd. ATK, Warszawa.

Tatarkiewicz W. (1990). O szczęściu. PWN, Warszawa.

Tyszka T. (1997). Psychologia zachowań ekonomicznych. PWN, Warszawa.

Urban B. (2000). Zaburzenia w zachowaniu i przestępczości młodzieży. Wyd. UJ, Kraków.

Urban B. (2007). Teoria resocjalizacji w strukturze nauk społecznych. W: B. Urban, J.M. Stanik (red.). Resocjalizacja, t. 1. PWN, Warszawa.

Vernant J.P. (1996). Źródła myśli greckiej. Tłum. J. Szacki. Wyd. Słowo/Obraz Terytoria, Gdańsk.

Witek S. (1988). System wartości preferowanych przez uczniów szkót średnich. „Nowa Szkoła", nr 4.

Wojciszke B. (1986). Struktura „Ja”, wartości osobiste i zachowania. Wyd. Ossolińskich, Wrocław.

Wojciszke B. (2003). Człowiek wśród ludzi. Zarys psychologii społecznej. Wyd. Naukowe Scholar, Warszawa. 
Wolicka E. (1989). Mit - symbol rozwinięty. W kręgu platońskiej hermeneutyki mitów. Wyd. UMCS, Lublin.

Woroniecki J. (1961). Wychowanie człowieka. Wyd. Znak, Kraków.

Zaleski Z. (1991). Psychologia zagadnień celowych. PWN, Warszawa.

Ziemska M. (1997). Typy postaw rodzicielskich. PWN, Warszawa, s. 170 i n.

Ziółkowski M. (1997). Interesy $i$ wartości społeczeństwa polskiego w okresie systemowej transformacji. „Forum Oświatowe - Polacy na Progu”, nr 1-2.

Znaniecki F. (2001). Socjologia wychowania. PWN, Warszawa.

Żelazny M. (1986). Metafizyka czasu i wieczności jako filozofia człowieka w idealizmie niemieckim od Kanta do Nietzschego. Wyd. UMK, Torun.

Życiński J. (1985). Teizm i filozofia analityczna. Wyd. Znak, Kraków.

\title{
THE PARADIGM OF IDENTITY AS THE FOUNDATION FOR CREATING \\ A MULTI-LEVEL AND INTEGRATED MODEL OF \\ SELF-RESOCIALIZATION TREATMENT
}

\begin{abstract}
Resocialization with the use of probation measures is the process of the development of theory and practical methods of dealing with persons who violate the legal order, within the institutionalized system of criminal-law responses. The originality and wide scope of probation is deeply-rooted in specialized assistance agencies, in innovative practice and in providing noninstitutional measures complementing the system of closed establishments and institutions for convicts. The presented extensive theoretical study made an in-depth, interdisciplinary analysis of the multi-level rehabilitation theory and principal paradigms that make up the phenomenon of the social integration and self-resocialization of the convicts. The conclusions resulting from this text will be especially useful in the work of resocialization officers, probation officers, social workers, and correction officers in penitentiary and socio-therapeutic institutions.
\end{abstract}

Key words: probation, social re-integration of convicts, identity, self-resocialization, criminal policy 